\title{
БОЛЕЗНИ SECALE CEREALE L. В КИРОВСКОЙ ОБЛАСТИ И ГЕНЕТИЧЕСКИЕ ИСТОЧНИКИ УСТОЙЧИВОСТИ ДЛЯ СЕЛЕКЦИИ ОЗИМОЙ РЖИ
}

\section{L.M. Shchekleina, T.K. Sheshegova}

\section{THE DISEASES SECALE CEREALE L. IN KIROV REGION AND GENETIC SOURCES OF SUSTAINABILITY FOR WINTER RYE SELECTION}

\begin{abstract}
Щеклеина Люция Муллаахметовна - канд. с.-х. наук, ст. науч. сотр. лаб. иммунитета и защиты растений Федерального аграрного научного центра Северо-Востока им. Н.В. Рудницкого, г. Киров. E-mail: immunitet@fanc-sv.ru
\end{abstract} Шешегова Татьяна Кузьмовна - д-р биол. наук, профр., гл. науч. сотр., зав. лаб. иммунитета и защиты растений Федерального аграрного научного центра Северо-Востока им. Н.В. Рудницкого, г. Киров. E-mail: sheshegova.tatyana@yandex.ru

Цель исследований - поиск генетических источников устойчивости озимой ржи к основным болезням в условиях Кировской области. $B$ условиях провокационно-инфекционного фона возбудителей снежной плесени, мучнистой росы, бурой и стеблевой ржавчины, корневых гнилей и спорыньи в ФГБНУ ФАНЦ СевероВостока в 2018-2019 годах изучено 30 новых популяций и районированных сортов озимой ржи селекции ФАНЦ Северо-Востока и 50 образцов из мировой коллекции ВИР. Среди образцов нашего института комплексной устойчивостью $к$ снежной плесени, бурой и стеблевой ржавчине обладают: Вятка 2, Кировская 89, Флора, Румба; к снежной плесени, мучнистой росе и корневым гнилям - Рада; к снежной плесени, мучнистой росе и бурой ржавчине - Триумф; к снежной плесени, стеблевой ржавчине и корневым гнилям - Гармония; к мучнистой росе и бурой ржавчине Рушник; к снежной плесени и мучнистой росе Грасрит; к снежной плесени и спорынье - Леда и Симфоония. Комплексную устойчивость проявляют коллекционные образцы: Тринодис 4 Минвак-139/09 НП - устойчивость к снежной плесени, мучнистой росе, бурой ржавчине и спорынье; Россиянка 2, Волжанка 2, Янтарная НП, Новая Эра НП, Красноярская универсаль-
Shchekleina Lucia Mullaakhmetovna - Cand. Agr. Sci., Senior Staff Scientist, Lab. of Plants Immunity and Protection, N. V. Rudnitsky Federal Agrarian Research Center of North-East, Kirov. E-mail: immunitet@fanc-sv.ru Sheshegova Tatyana Kuzmovna - Dr. Biol. Sci., Prof., Chief Staff Scientist, Head, Lab. of Plants Immunity and Protection, N. V. Rudnitsky Federal Agrarian Research Center of North-East, Kirov.

E-mail: sheshegova.tatyana@yandex.ru

ная НП - к снежной плесени, мучнистой росе $u$ спорынье; Чулпан 4 и Таловская 2 - к снежной плесени, бурой ржавчине и спорынье; Чулыш и Заречанская 3 - к мучнистой росе и бурой ржавчине; Чулпан 2 - к мучнистой росе и спорынье; Подарок НП - к снежной плесени и спорынье. Обнаружено, что низкопентозановые сорта значительно меньше, чем высокопентозановые, поражаются спорыньей и снежной плесенью. В среднем по группам образцов отрастание растений после поражения снежной плесенью у низкопентазановых образцов было в 2,4 раза выше, а поражение посевов спорыньей - в 2 раза, засоренность зерновой массы склероциями спорыньи - в 4 раза.

Ключевые слова: озимая рожь, сорт, селекция, коллекция ВИР, болезни, провокационно-инфрекционные фоны, оценка, источники.

The purpose of the study was the search for genetic sources of resistance of winter rye to the main diseases in Kirov Region. In terms of provocative infectious background of snow mold pathogens, powdery mildew, leaf and stem rust, root rot and ergot in FSBRI FARC of the North-East in 2018201930 the populations and cultivars of winter rye breeding FARC the North-East and 50 samples from world collection of VIR were studied. Among 
the samples of the Institute complex resistance to snow mold, leaf and stem rust have: Vyatka 2, Kirovskaya 89, Flora, Rumba; to snow mold, powdery mildew and root rots - Rada; to snow mold, powdery mildew and brown rust - Triumph; to snow mold, stem rust and root rots - Harmony; to powdery mildew and brown rust - Rushnik; to snow mold and powdery mildew - Graphite; to snow mold and ergot - Leda and the Symphony. Complex stability was shown by collection samples: Trinodis 4 - Minvak-139/09 NP - resistance to snow mold, powdery mildew, brown rust and ergot; Rossiyanka 2, Volzhanka 2, Yantarnaya NP, Novaya Era NP, Krasnoyarskaya universalnaya NP to snow mold, powdery mildew and ergot; Chulpan 4 and Talovskaya 2 - snow mold, brown rust and ergot; Chulysh and Zarechanskaya 3 - to powdery mildew and brown rust; Chulpan 2 - to powdery mildew and ergot; Podarok NP - to snow mold, and ergot. It was discovered that low pentasan varieties had been much less than high pentasan affected by ergot and snow mold. On average, the groups of the samples regrowth of plants after the defeat of the snow mold from low pentasan samples was 2.4 times higher, and the crops defeatedby ergot- 2 times the grain mass contamination with ergot sclerotia - 4 times.

Keywords: winter rue, variety, selection, VIR collection, diseases, provocatively infectious backgrounds, assessment, sources.

Введение. В настоящее время в селекции озимой ржи остро встает вопрос поиска эффективных генов многих селекционно-ценных признаков. Обновление генетического материала за счет привлечения новых исходных форм является базисом селекции любой сельскохозяйственной культуры. Для эффективного создания новых конкурентоспособных сортов необходимо располагать генетически разнообразным и комплексно изученным исходным материалом, который составляет основу селекционного улучшения растений [1]. Это особенно важно в селекции на иммунитет к экономически значимым болезням, поскольку резерв устойчивости возделываемых сортов исчерпан или почти исчерпан. Донорный фонд постоянно меняется вследствие преодоления патогенами генов устойчивости и в связи с тем, что прежние доноры морально устаревают, т.е. их хо- зяйственно полезные свойства отстают от уровня, достигнутого в отечественной и мировой селекции. Успех селекции устойчивых сортов часто зависит от приоритетов в селекции на иммунитет и насколько исходный материал обладает генетическим разнообразием, способным сдерживать развитие болезней в зоне исследований [2-6]. Ведется постоянный поиск эфффективных генов устойчивости и научная проработка генетического разнообразия озимой ржи по адаптивно важным признакам среди местных популяций и сортов, селекционных сортов, относящихся к другому климатическому району, и образцов мировых коллекций. В настоящее время в 94 генбанках мира хранится 22200 образцов рода Secale озимых и яровых форм. Крупнейший генный банк (3260 образцов) находится в России, это ФИЦ «Всероссийский институт генетических ресурсов растений им. Н.И. Вавилова» (ВИР) [7]. В различных странах имеются обширные коллекции, содержащие местные сорта из Европы, Северной Америки, Азии, Южной Америки, Африки и Ближнего Востока [8]. Чем больше и разнообразнее источников устойчивости включается в селекцию, тем больше возникает возможностей получить совершенно новые формы растений с обогащенным генофондом. Наиболее значимые коллекции ржи (1000-6500 образцов) находятся: В Санкт-Петербурге (Россия); Gatersleben (Германия); Radzików, Warsawa (Польша); Aberdeen, Idaho (США); Saskatoon, Saskatchewan (Канада) и Sadovo (Болгария) [9].

Оценка устойчивости к болезням и поиск генетических источников эфффективны лишь в условиях естественных или искусственных эпифитотий. Моделирование фитопатоценозов в ФАНЦ Северо-Востока проводится с включением в патологический процесс искусственных или природных популяций возбудителей снежной плесени (Microdochium nivale (Fr.) Samuels Hallete), фузариоза колоса и корневых гнилей (Fusarium Link.: $F$. culmorum (W.G.Sm.) Sacc, F. sporotrichioides Sherb. Fusarium graminearum Schwabe., F. avenaceum (Fr.) Sacc., F. poae (Peck) Wollenw и др.), спорыньи (Claviceps purpurea (Fr.) Tul.), мучнистой росы (Blumeria graminis (DC.) Speer f. sp. secalis Marchal.), бурой ржавчины (Puccinia dispersa Eriks. et. Henn.) и стеблевой ржавчины (Puccinia graminis Pers. f. sp. secalis Eriks. et.). 
Озимая рожь - вторая хлебная и наиболее ценная кормовая культура, которую возделывают прежде всего в России, Германии, Польше, Беларуси, Украине, Скандинавии, Китае, Канаде и США. Посевные площади, отведенные под выращивание ржи, сокращаются. Во всех зонах возделывания рожь заслужила репутацию наиболее приспособленной к климатическим условиям страховой культуры низкого экономического риска. Для Кировской области, занимающей четвертую по величине посевную площадь озимой ржи в Российской Федерации, вопросы устойчивости к болезням являются первостепенными. На фоне постоянного удорожания пестицидов и экологической нестабильности особое значение приобретает поиск и создание новых эффективных источников устойчивости для селекции. Поэтому мы активно изучаем в наших агроэкологических условиях коллекцию генетических ресурсов ржи, созданную В.Д. Кобылянским на основе эффрективных доноров групповой устойчивости ржи, обладающих ценными селекционными признаками.

Цель исследований. Поиск генетических источников устойчивости озимой ржи к основным болезням в условиях Кировской области.

Условия, материал и методы исследований. Исследования проводили на фитопатологическом участке ФГБНУ ФАНЦ Северо-Востока в 2018-2019 гг. Объектами исследования являлись 30 популяций и районированных сортов озимой ржи селекции ФАНЦ Северо-Востока и 50 образцов из мировой коллекции ФИЦ «Всероссийский институт генетических ресурсов растений им. Н.И. Вавилова» (ВИР). Изучение исходного материала проводили на естественном (без заражения) и инфекционном (искусственная инокуляция) фоне возбудителей грибных болезней: снежной плесени, мучнистой росы, бурой и стеблевой ржавчины, корневых гнилей, спорыньи. При создании искусственных инфрекционных фонов и учетов поражения использовали общеизвестные методики: М.Ф. Григорьева ${ }^{1}$ (1976); В.Д. Кобылянского, Л.А. Королевой 2 (1977); В.К. Неосритовой ${ }^{3}$ (1976); [10-12].

Схема закладки фритопитомников следующая: стандарт $\rightarrow$ (сорт, рекомендованный Го- сударственной комиссией по сортоиспытанию) $\rightarrow$ индикаторные сорта (наиболее устойчивый и восприимчивый) $\rightarrow$ опытные образцы. Повторность в полевых опытах 2-кратная при систематическом размещении делянок со смещением. Площадь делянок $1 \mathrm{~m}^{2}$. Диагностику и учеты развития болезней проводили в период максимального их проявления. К источникам устойчивости относили сорта или образцы, сохраняющие иммунитет или высокую устойчивость (6-9 баллов) в течение не менее 2 лет изучения в условиях жесткого инфекционного (провокационного) фона.

Для обработки результатов исследований применяли пакет селекционно-ориентированных и биометрико-генетических программ AGROS, версия 2.07 и пакет прикладных программ Мicrosoft Excel.

Результаты исследований и их обсуждение. Изучение новых популяций и районированных сортов озимой ржи селекции ФАНЦ СевероВостока в условиях провокационно-инфекционных фонов выявило широкую диффференциацию геносоонда по восприимчивости к основным грибным болезням. Большинство сортов характеризуются высокой регенерационной способностью после поражения снежной плесенью, которая составила в среднем 70 \% (от 50 до $100 \%$ ). Наилучшее состояние признака (от 70 до $100 \%$ ) выявлено у 15 популяций и селекционных образцов ржи: Графит, Румба, Вятка 2, Кировская 89, Флора, Рада, Триумф, Гармония, Кипрез, Садко, Леда, Симфония, Сармат, Ниоба и Сара (табл. 1).

Развитие мучнистой росы у большинства сортов было средним (около $23 \%$ ). Устойчивость к мучнисторосяной инфекции проявили 5 из них (Рада, Графит, Триумф, Графиня, Рушник), степень поражения которых была на уровне $15 \%$.

Нарастание ржавчинной инфекции в исследуемые годы имело относительно медленные темпы из-за недостатка эфффективных температур в период «выход в трубку-цветение». Развитие стеблевой формы ржавчины было слабым (не более $25 \%$ ) из-за пониженного температурного фона. Максимальное количество пустул патогена (5 \%) отмечено у сортов: Вятка 2, Кировская 89, Кировская 89, Флора, Снежана,

1Григорьев М.Ф. Методические указания по изучению устойчивости зерновых культур к корневым пнилям. Л., 1976. 60 с.

2Кобь ияянский В.Д., Королева Л.А. Методические указания по селекции озимой ржи на устойчивость к грибным болезням. Л., 1977.26 с. зНеофитова В.К. Методы полевой оценки устойчивости сортов озимых зерновых культур к снежной плесени. Минск, 1976. 4 с. 
Румба, Гармония и Перепел. Относительно меньшее проявление болезни (40-45\%) было у сортов Вятка 2, Кировская 89, Снежана, Рушник, Флора, Румба и Триумф.

Высокую устойчивость к фузириозным корневым гнилям (развитие болезни до 10,0 \%) проявили 16 изучаемых сортов ржи. Среди них наименьшее развитие болезни выявлено у 5 образцов: Рада (3,2 \%), Фаленская 4 (3,5\%), Гармония $(3,7 \%)$, Снежана (3,9\%), Перепел (4,9\%) при значении признака у индикаторного сорта $23,0 \%$.

Поражение сортов спорыньей при искусственной инокуляции цветков конидиями С. purpurea было высоким и изменялось от 19,2 \% (Симфония) до 78,5 \% (Ниоба). Хотя все сорта на этом фоне характеризуются как восприимчивые к спорынье, относительно меньшее (14,2$35,7 \%$ проявление болезни было у сортов Леда, Симфония, Гармония и Румба. Засоренность зерновой массы склероциями спорыньи была на уровне от 0,7 до 7,7 \% от веса зерна. По двум показателям, относительно в меньшей степени поразились спорыньей лишь два сорта озимой ржи: Леда (поражение 14,2 \%, засоренность 0,7 \%) и Симфония (поражение 19,3 \%, засоренность 1,3\%).

Источники с высоким уровнем неспецифической устойчивости к грибным болезням озимой ржи селекции ФАНЦ Северо-Востока

Таблица 1

\begin{tabular}{|l|c|}
\hline \multicolumn{1}{|c|}{ Патоген } & Образцы с высоким уровнем неспецифической устойчивости \\
\hline Снежная плесень & $\begin{array}{c}\text { Вятка 2, Кировская 89, Флора, Рада, Графит, Румба, Триумф, } \\
\text { Гармония, Кипрез, Садко, Леда, Симфония, Сармат, Ниоба, Сара }\end{array}$ \\
\hline Мучнистая роса & Рада, Графит, Триумф, Графиня, Рушник \\
\hline Бурая ржавчина & Вятка 2, Кировская 89, Снежана, Рушник, Флора, Румба, Триумф \\
\hline Стеблевая ржавчина & Вятка 2, Кировская 89, Снежана, Флора, Румба, Гармония, Перепел \\
\hline Корневые гнили & Рада, Фаленская 4, Гармония, Снежана, Перепел \\
\hline Спорынья & \multicolumn{2}{|c|}{ Леда, Симфония } \\
\hline
\end{tabular}

Среди выделенных новых популяций и районированных сортов селекции ФАНЦ Северо-Востока с групповой устойчивостью к трем и более болезням характеризуются следующие: Вятка 2, Кировская 89, Флора, Румба к снежной плесени, бурой и стеблевой ржавчине; Рада к снежной плесени, мучнистой росе и корневым гнилям; Триумф к снежной плесени, мучнистой росе и бурой ржавчине; Гармония к снежной плесени, стеблевой ржавчине и корневым гнилям; Рушник к мучнистой росе и бурой ржавчине; Графит к снежной плесени и мучнистой росе; Леда и Симфония к снежной плесени и спорынье.
На провокационно-инфекционных фонах изучали также образцы озимой ржи из мировой коллекции ВИР, среди которых были и низкопентозановые сорта (НП) универсального использования. Основной их недостаток - они плохо зимуют и в условиях Кировской области сильно поражаются снежной плесенью. Исследования показали, что наиболее высокой выносливостью к снежной плесени (50-60 \%) отличаются 10 образцов: Россиянка 2, Таловская 2, Волжанка 2, Янтарная НП, Новая Эра НП, Подарок НП, Красноярская универсальная НП, Берегиня НП, Московская ВИР-12-244/16 НП, Тринодис 4 - Минвак-139/09 НП (табл. 2). 
Комплексно-устойчивые образцы озимой ржи из мировой коллекции ВИР (провокационно-инфекционные фоны)

\begin{tabular}{|c|c|c|c|c|c|c|c|}
\hline \multirow{3}{*}{$\begin{array}{l}\text { Каталог } \\
\text { ВИР }\end{array}$} & \multirow{3}{*}{ Образец } & \multirow{2}{*}{\multicolumn{2}{|c|}{$\begin{array}{l}\text { Снежная } \\
\text { плесень }\end{array}$}} & \multicolumn{2}{|c|}{ Спорынья } & $\begin{array}{l}\text { Мучни- } \\
\text { стая } \\
\text { роса }\end{array}$ & $\begin{array}{c}\text { Бурая } \\
\text { ржавчи- } \\
\text { на } \\
\end{array}$ \\
\hline & & & & \multirow{2}{*}{$\begin{array}{c}\text { Пораже- } \\
\text { ние, \% }\end{array}$} & \multirow{2}{*}{$\begin{array}{c}\text { Засоренность } \\
\text { зерновой массы } \\
\text { склероциями, \% }\end{array}$} & \multirow{2}{*}{\multicolumn{2}{|c|}{$\begin{array}{c}\text { Степень } \\
\text { поражения, } \\
\%\end{array}$}} \\
\hline & & \multirow{2}{*}{$\begin{array}{c}\text { Пораже- } \\
\text { ние, \% } \\
100,0\end{array}$} & \multirow{2}{*}{$\begin{array}{c}\text { Отрас- } \\
\text { тание, \% } \\
100,0\end{array}$} & & & & \\
\hline \multicolumn{2}{|c|}{ Фаленская 4 - стандарт } & & & 40,7 & 3,5 & 10,0 & 15,0 \\
\hline 11856 & $\begin{array}{l}\text { Тринодис } 4 \text { - } \\
\text { Минвак-139/09 НП }\end{array}$ & 100,0 & 50,0 & 16,6 & 0,6 & 10,0 & 15,0 \\
\hline 11671 & Россиянка 2 & 70,0 & 50,0 & 17,6 & 0,9 & 15,0 & 30,0 \\
\hline 11682 & Волжанка 2 & 80,0 & 50,0 & 33,3 & 1,7 & 5,0 & 30,0 \\
\hline 11804 & Янтарная НП & 80,0 & 60,0 & 43,7 & 1,9 & 15,0 & 20,0 \\
\hline 11814 & Новая Эра НП & 80,0 & 60,0 & 25,0 & 2,4 & 15,0 & 40,0 \\
\hline 11816 & Подарок НП & 80,0 & 50,0 & 5,8 & 0,3 & 20,0 & 60,0 \\
\hline 11818 & $\begin{array}{l}\text { Красноярская } \\
\text { универсальная НП }\end{array}$ & 80,0 & 50,0 & 18,7 & 0,8 & 5,0 & 40,0 \\
\hline 11378 & Чулпан 4 & 100,0 & 40,0 & 31,2 & 1,4 & 5,0 & 15,0 \\
\hline 11674 & Таловская 2 & 60,0 & 50,0 & 25,0 & 1,9 & 20,0 & 15,0 \\
\hline 11677 & Чулпан 2 & 80,0 & 40,0 & 14,2 & 0,6 & 5,0 & 30,0 \\
\hline 11493 & Чулыш & 100,0 & 10,0 & 22,2 & 11,2 & 5,0 & 10,0 \\
\hline 11451 & Заречанская 3 & 90,0 & 5,0 & 50,0 & 2,6 & 5,0 & 5,0 \\
\hline \multicolumn{8}{|c|}{ Индикаторные сорта: } \\
\hline 11820 & Рушник $2 \mathrm{HП}$ & 100,0 & - & - & - & 50,0 & 60,0 \\
\hline 11513 & Компус & - & 5,0 & - & 37,0 & - & - \\
\hline 11489 & Беняконская 2 & - & - & 100,0 & - & - & - \\
\hline
\end{tabular}

Большинство образцов слабо поразились мучнистой росой $(0-15 \%)$ и относительно меньше, чем сорта селекции нашего института, - бурой ржавчиной.

Поражение спорыньей изменялось в значительных пределах - от 5,8 до $100 \%$. Относительно меньшее проявление болезни (от 5,8 до $25 \%)$ выявлено у образцов: Подарок НП, Чулпан 2, Вавиловская НП, Тринодис 4 - Минвак139/09 НП, Россиянка 2, Красноярская универсальная НП, Чулыш, Таловская 2 и Новая Эра НП. Засоренность зерновой массы склероциями изменялась от 0,3 \% (Подарок НП) до 37,0 \% (Компус). По двум показателям наименьшая восприимчивость к спорынье у следующих образцов: Подарок НП (поражение 5,8 \% и засоренность 0,3 \%), Чулпан 2 (14,2 и 0,6 \%), Тринодис 4 - Минвак-139/09 НП (16,6 и 0,6 \%), Россиянка 2 (17,6 и 0,9\%), Красноярская универсальная НП (18,7 и 0,8 \%) и Вавиловская НП (15,3 и $1,0 \%)$.
Лучшие коллекционные образцы с групповой устойчивостью к четырем и более болезням можно характеризовать следующим: Тринодис 4 - Минвак-139/09 НП - устойчивость к снежной плесени, мучнистой росе, бурой ржавчине и спорынье; Россиянка 2, Волжанка 2, Янтарная НП, Новая Эра НП, Красноярская универсальная НП - к снежной плесени, мучнистой росе и спорынье; Чулпан 4 и Таловская 2 - к снежной плесени, бурой ржавчине и спорынье; Чулпан 2 - к мучнистой росе и спорынье; Подарок НП - к снежной плесени и спорынье; Чулыш и Заречанская 3 - к мучнистой росе и бурой ржавчине. Данные образцы перспективны для использования в селекционных программах по повышению фитоиммунитета.

В ходе иммунологического анализа обнаружено, что низкопентозановые сорта тестируемых коллекционных образцов значительно меньше, чем высокопентозановые, поражаются спорыньей и снежной плесенью (табл. 3). По признаку 
«поражение» она составила 27,1 \%, по «засоренности зерновой массы склероциями» - 1,6\%, у другой группы образцов соответственно 53,5 и $6,4 \%$. Низкопентозановые сорта также более выносливы к снежной плесени: отрастание после поражения составило 45,6 \%, у другой группы 18,7 \%. В среднем по группам образцов отрастание растений после поражения снежной плесе- нью у низкопентозановых сортов было в 2,4 раза выше, поражение посевов спорыньей - в 2 раза, засоренность зерновой массы склероциями спорыньи - в 4 раза. Выявленная тенденция предполагает возможность более широкого использования низкопентозановых сортов, пригодных для кормовой промышленности, особенно в регионах, где данные болезни наиболее актуальны.

Таблица 3

\section{Характер проявления грибных болезней у низкопентозановых и высокопентозановых сортов озимой ржи (в среднем по группам), \%}

\begin{tabular}{|c|c|c|c|c|}
\hline \multirow{2}{*}{ Болезнь } & \multicolumn{2}{|c|}{ Низкопентозановые сорта } & \multicolumn{2}{|c|}{ Высокопентозановые сорта } \\
\hline & lim признака & В среднем & lim признака & В среднем \\
\hline \multicolumn{5}{|l|}{ Снежная плесень: } \\
\hline поражение & $50,0-100$ & 82,2 & $60,0-100$ & 88,3 \\
\hline отрастание & $20,0-60,0$ & 45,6 & $5,0-50,0$ & 18,7 \\
\hline \multicolumn{5}{|l|}{ Мучнистая роса: } \\
\hline степень поражения & $5,0-50,0$ & 26,1 & $0-20,0$ & 7,8 \\
\hline \multicolumn{5}{|l|}{ Бурая ржавчина: } \\
\hline степень поражения & $15,0-60,0$ & 40,6 & $5,0-50,0$ & 21,9 \\
\hline \multicolumn{5}{|l|}{ Спорынья: } \\
\hline поражение & $5,8-41,1$ & 27,1 & $14,2-100$ & 53,5 \\
\hline $\begin{array}{l}\text { засоренность зерновой } \\
\text { массы склероциями }\end{array}$ & $0,3-3,0$ & 1,6 & $0,6-37,0$ & 6,4 \\
\hline
\end{tabular}

Примечание: достоверно к стандарту Фаленская 4 при $\mathrm{P} \geq 095$.

Выводы. Таким образом, выявленные устойчивые формы в селекционном и коллекционном генофоонде озимой ржи могут быть использованы в качестве генетических источников в программах по повышению устойчивости к этим болезням. Выявлена более высокая устойчивость к спорынье у низкопентозановых сортов по сравнению с высокопентозановыми. Кроме того, они более выносливы к основному заболеванию озимой ржи в нашей зоне - снежной плесени, что делает их достаточно перспективными для селекции ржи на Северо-Востоке Нечерноземной зоны Российской Федерации.

\section{Литература}

1. Пономарева М.Л., Пономарев С.Н., Маннапова Г.С. Исходный материал для селекции озимой ржи (SECALE CEREALE L.) // Вестник КрасГАУ. 2018. № 3. С. 19-24.

2. Каширкин А.Д., Макаров А.А. Метод предварительной оценки полевой устойчивости к бурой ржавчине // Вестник защиты растений. 2011. № 1. С. 27-33.

3. Бабаянц О.В., Сауляк H.І., Бабаянц Л.T. [и др.]. Новый исходный материал для селекции пшеницы (Triticum aestivum L.) на групповую устойчивость к фритопатогенам // Збірник наукових праць Селекційно-генетичного інституту-Національного центру насіннезнавства та сортовивчення. 2016. № 28. С. 68-75.

4. Пономарев С.Н., Пономарева М.Л., Маннапова Г.С. Болезни озимой ржи в Северном Повольжье и генетические источники устойчивости // Успехи современной науки. 2017. № 10. T. 1. С. 130-138.

5. Пономарева М.Л., Пономарев С.Н., Маннапова, Г.С. [и др.]. Фитосанитарный мониторинг наиболее вредоносных болезней озимой ржи в Республике Татарстан // Вестник КрасГАУ. 2019. № 9. С. 27-34.

6. Щеклеина Л.М., Шешегова Т.К. Иммунологическая оценка коллекционных образцов озимой ржи в условиях Кировской области // Методы и технологии в селекции растений и 
растениеводстве: мат-лы V междунар. НПК. Киров: НИИСХ Северо-Востока, 2019. C. 180-183.

7. Сафонова И.В., Аниськов Н.И., Кобылянский В.Д. База данных генетических ресурсов коллекции озимой ржи ВИР как средство классификации генетического разнообразия, анализа истории коллекции и эфффективного изучения и сохранения // Вавиловский журнал генетики и селекции. 2019. № 23(6). C. 780-786. DOI: $10.18699 /$ VJ19.552.

8. Шлегель P. Селекция гибридных форм как стимул развития молекулярно-генетических исследований у ржи // Вавиловский журнал генетики и селекции. 2015. Т. 19(5). С. 589603. DOI: $10.18699 / \mathrm{VJ} 15.076$.

9. Schlegel Rolf H.J. Rye: genetics, breeding and cultivation. CRC Press Taylor \& Francis Group. 2013. 359 p.

10. Кобылянский В.Д., Сафонова И.В., Солодухина О.В. [и др.]. Изучение и сохранению мировой коллекции ржи: метод. указания. СПб.: ВИР, 2015. С. 44.

11. Шешегова Т.К., Щеклеина Л.М., Кедрова Л.И. [и др.]. Селекция озимой ржи на устойчивость к спорынье: метод. пособие. Киров: Вятская ГСХА, 2018. 27 с.

12. Miedane T., Mirdita V., Rodeman B., Drobeck $T$., Rentel $D$. Genetic variation of winter rye cultivars for their ergot (Claviceps. purpurea) reaction tested in a field design with minimized interplot interference. Plant Breed. 2010. 129. 58-62. DOI: 10.1007/s10681-009-0083-5.

\section{Literatura}

1. Ponomareva M.L., Ponomarev S.N., Mannapova G.S. Ishodnyj material dlja selekcii ozimoj rzhi (SECALE CEREALE L.) // Vestnik KrasGAU. 2018. № 3. S. 19-24.

2. Kashirkin A.D., Makarov A.A. Metod predvaritel'noj ocenki polevoj ustojchivosti $\mathrm{k}$ buroj rzhavchine // Vestnik zashhity rastenij. 2011. № 1. S. 27-33.

3. Babajanc O.V., Sauljak N.I., Babajanc L.T. [i dr.]. Novyj ishodnyj material dlja selekcii pshenicy (Triticum aestivum L.) na gruppovuju ustojchivost' k fitopatogenam // Zbirnik naukovih prac' Selekcijno-genetichnogo institutu-
Nacional'nogo centru nasinneznavstva ta sortovivchennja. 2016. № 28. S. 68-75.

4. Ponomarev S.N., Ponomareva M.L., Mannapova G.S. Bolezni ozimoj rzhi v Severnom Povol'zh'e i geneticheskie istochniki ustojchivosti // Uspehi sovremennoj nauki. 2017. № 10. T. 1. S. 130-138.

5. Ponomareva M.L., Ponomarev S.N., Mannapova, G.S. [i dr.]. Fitosanitarnyj monitoring naibolee vredonosnyh boleznej ozimoj rzhi v Respublike Tatarstan // Vestnik KrasGAU. 2019. № 9. S. 27-34.

6. Shhekleina L.M., Sheshegova T.K. Immunologicheskaja ocenka kollekcionnyh obrazcov ozimoj rzhi v uslovijah Kirovskoj oblasti // Metody i tehnologii v selekcii rastenij i rastenievodstve: mat-ly $\mathrm{V}$ mezhdunar. NPK. Kirov: NIISH Severo-Vostoka, 2019. S. 180183.

7. Safonova I.V., Anis'kov N.I., Kobyljanskij V.D. Baza dannyh geneticheskih resursov kollekcii ozimoj rzhi VIR kak sredstvo klassifikacii geneticheskogo raznoobrazija, analiza istorii kollekcii i jeffektivnogo izuchenija i sohranenija // Vavilovskij zhurnal genetiki i selekcii. 2019. № 23(6). S. 780-786. DOI: 10.18699/NJ19.552.

8. Shlegel' $R$. Selekcija gibridnyh form kak stimul razvitija molekuljarno-geneticheskih issledovanij u rzhi // Vavilovskij zhurnal genetiki i selekcii. 2015. T. 19(5). S. 589-603. DOI: 10.18699/ VJ15.076.

9. Schlegel Rolf H.J. Rye: genetics, breeding and cultivation. CRC Press Taylor \& Francis Group. 2013. 359 p.

10. Kobyljanskij V.D., Safonova I.V., Soloduhina O.V. [i dr.]. Izuchenie i sohraneniju mirovoj kollekcii rzhi: metod. ukazanija. SPb.: VIR, 2015. C. 44.

11. Sheshegova T.K., Shhekleina L.M., Kedrova L.I. [i dr.]. Selekcija ozimoj rzhi na ustojchivost' k sporyn'e: metod. posobie. Kirov: Vjatskaja GSHA, 2018. $27 \mathrm{~s}$.

12. Miedane T., Mirdita V., Rodeman B., Drobeck $T$., Rentel $D$. Genetic variation of winter rye cultivars for their ergot (Claviceps. purpurea) reaction tested in a field design with minimized interplot interference. Plant Breed. 2010. 129. 58-62. DOI: 10.1007/s10681-009-0083-5. 